\title{
The future and the role of human resource management in South Africa during the Fourth Industrial Revolution
}

\begin{tabular}{|c|c|}
\hline \multicolumn{2}{|c|}{$\begin{array}{l}\text { Author: } \\
\text { Cecilia M. Schultz }{ }^{1} \text { (D) }\end{array}$} \\
\hline \multicolumn{2}{|c|}{$\begin{array}{l}\text { Affiliation: } \\
{ }^{1} \text { Department of People } \\
\text { Management and } \\
\text { Development, Faculty of } \\
\text { Management Sciences, } \\
\text { Tshwane University of } \\
\text { Technology, Pretoria, } \\
\text { South Africa }\end{array}$} \\
\hline \multicolumn{2}{|c|}{$\begin{array}{l}\text { Corresponding author: } \\
\text { Cecilia Schultz, } \\
\text { schultzcm@tut.ac.za }\end{array}$} \\
\hline \multicolumn{2}{|c|}{$\begin{array}{l}\text { Dates: } \\
\text { Received: } 05 \text { Apr. } 2021 \\
\text { Accepted: } 12 \text { Oct. } 2021 \\
\text { Published: } 17 \text { Dec. } 2021\end{array}$} \\
\hline \multicolumn{2}{|c|}{$\begin{array}{l}\text { How to cite this article: } \\
\text { Schultz, C.M. (2021). } \\
\text { The future and the role } \\
\text { of human resource } \\
\text { management in South Africa } \\
\text { during the Fourth Industrial } \\
\text { Revolution. SA Journal of } \\
\text { Human Resource } \\
\text { Management/SA Tydskrif vir } \\
\text { Menslikehulpbronbestuur, } \\
\text { 19(0), a1624. https://doi. } \\
\text { org/10.4102/sajhrm. } \\
\text { v19i0.1624 }\end{array}$} \\
\hline \multicolumn{2}{|c|}{$\begin{array}{l}\text { Copyright: } \\
\text { (C) 2021. The Author. } \\
\text { Licensee: AOSIS. This w } \\
\text { is licensed under the } \\
\text { Creative Commons } \\
\text { Attribution License. }\end{array}$} \\
\hline \multicolumn{2}{|c|}{ Read online: } \\
\hline 口ifi: & $\begin{array}{l}\text { Scan this QR } \\
\text { code with your } \\
\text { smart phone or } \\
\text { mobile device } \\
\text { to read online. }\end{array}$ \\
\hline
\end{tabular}

Orientation: The world of work is evolving at an alarming rate, and human resource (HR) practitioners need to familiarise themselves with the future of human resource management (HRM) in order to add value to their organisations.

Research purpose: This article presents South African HR practitioners' views about the future and the role of HRM in the Fourth Industrial Revolution (4IR) from a qualitative perspective.

Motivation for the study: Human resource practitioners play a central role in the 4IR, but theories on how their role is enacted remain insufficient.

Research approach/design and method: A qualitative survey design was used to study the views of $105 \mathrm{HR}$ practitioners affiliated with the South African Board of People Practices. Three open-ended questions were sent to participants by means of a SurveyMonkey link. Deductive and inductive coding were used to thematically analyse the data.

Main findings: The following themes were identified: technology-driven, data-driven, ethically driven, change driven, business-driven, human-machine collaboration and presilience.

Practical/managerial implications: South African HR practitioners should be prepared for the future world of work. If these HR practitioners are not technology-driven, data-driven, ethically driven, change driven, business-driven, human-machine collaboration and presilient, they may have difficulty to add value to the organisation in the 4IR.

Contribution/value-add: This study extends the body of knowledge about the future world of work and the role of HRM in South Africa by founding that HR practitioners must have presilience and respect $u b u n t u$. The study also extends contemporary scholarship by using an open-ended qualitative review design to investigate the future of HRM in South Africa during the $4 \mathrm{IR}$.

Keywords: future human resource management; role of human resource management; Fourth Industrial Revolution; qualitative survey; South Africa.

\section{Introduction}

The pace of transformation in the business landscape has made it mandatory for the human resource (HR) role within the organisation to evolve, adapt and adjust to the demands of the Fourth Industrial Revolution (4IR) (Thomas, Kureshi, Suggala, \& Mendonca, 2020). This is also relevant within the South African organisational context (Bothma, 2019; Patel, 2019). The concept of the 4IR is accepted as a real and irreversible phenomenon, which is set to change all aspects of HR profoundly.

\section{Tarry (2018) advises:}

The first revolution was steam powered mechanisation in 1784, followed by the 2nd, with electricity enabling mass production from 1890. The 3rd was the IT and electronics revolution ushered in from 1969, which gained momentum and evolved into digital technology beyond the 1980s taking us to the edge of the 4 th digital revolution, when we see artificial intelligence (AI), biotechnology and the Internet of Things completely changed our world. (p. 1)

In the 4IR, companies face the challenge of motivating their knowledge workers to release their human potential (Xu, David, \& Kim, 2018). The HR department should be able to transform during the 4IR (Bissola \& Imperatori, 2018). This department needs to be involved in identifying the roles that should be filled by humans exclusively. In identifying the required skills, HR teams 
should develop staff internally and recruit the required talent externally. Human resource departments further will have to assist employees in adjusting and staying relevant in the new world of work (Pandian, 2018). Thus, HR departments should start planning for the necessary changes to meet the demands of digital transformation of the enterprise and seize the opportunities to improve HR capabilities, service offerings and performance (DiRomualdo, El-Khoury, \& Girimonte, 2018). Human resource departments further need to focus on the long-term objectives and future-oriented plans of their organisations. Instead of focusing on internal HR issues exclusively, HR departments need to take a balanced, broad approach (Kapoor \& Sherif, 2012).

In the South African context, the transition to 4IR has skills implication for HR practitioners (Dhanpat et al., 2020; Maisiri \& Van Dyk, 2021). Bothma (2019) urged South African HR practitioners to prepare and get ready for the 4IR. Ngwenya, Aigbavboa and Thwala (2019) are of the opinion that HR practitioners should realise the benefits of human resource information systems in South Africa. Mefi and Asoba found that in South Africa, human resource management (HRM) will need to have human-technology interface competencies and pay attention to talent management, Smart HR 4.0, digitalisation, remote HRM and HRM 4.0 policy development. Ayentimi and Burgess (2019) argued that policy development towards the 4IR in the sub-Sahara Africa region, given its young population profile and emerging skill shortages in key sectors, needs to obtain the necessary attention.

\section{Research purpose}

The literature on HR in South Africa remains fragmented in terms of scale, scope and reaching distinct scholarly communities (Wood \& Bischoff, 2020). A study by Pietersen (2018) indicated that the future of HR studies and studies on the role of HR in the 4IR in South Africa are limited. In the light of the limited literature available on the future of HR in South Africa, the following research gap was identified for the present study: What does the future of HR entail and what will the role of HR be in the 4IR? This knowledge is essential in preparing HR for the future world of work in a South African context. A qualitative approach was chosen because of the pioneering nature of this study to obtain rich and new data about the future of HR. The purpose of this research therefore was to provide a qualitative perspective on the future of HR and to focus on the role of HR in a South African context.

This study used Brockbank, Ulrich, Kryscynski and Ulrich (2018), Silver (2018), Wilkesmann and Wilkesmann (2018) and Calitz, Poisat and Cullen (2017) as theoretical grounding. From an academic point of view, this study broadened the body of knowledge regarding the future of HR and enhanced an understanding of the new roles and confirmed important current roles of HR that will still be relevant in the 4IR. The study further extends contemporary scholarship by using an open-ended approach to investigate the future of HR. Overall, this study extended the body of knowledge about the future of HR, specifically in terms of presilience. The possibility that employees may experience fear because of possible retrenchments as a result of automation featured a few times in the study, corroborating existing workforce trends in the adoption of new technologies.

The empirical contribution entails the importance of ethical behaviour and the role of the African concept ubuntu in accentuating humanity in the future of work. Presilience as a theme contributed to new knowledge regarding the future of HR. This approach presented an important methodological advancement to obtain rich data for future studies in the field. It could be said that the study adopted a pioneering approach in approaching the future of $\mathrm{HR}$.

\section{Literature review}

The future of human resources management and the role of human resources management in the 4IR are discussed below.

\section{The future of human resources management}

To keep up with the pace of the 4IR and function efficiently, a clear focus on technology and the automation of HR processes, agility, innovation, productivity, saving costs and the ability to remain competitive is necessary. The evolution of cloud computing and the development of new architectures and computational principles lead to the transformation of software and may bring radical changes in the business strategies of companies across all sectors of the economy (Gokhberg, Sokolov, \& Chulok, 2017). Considering the impact of technologies such as cloud applications and AI and the digitisation of operations, the work roles most likely to be eliminated are those involving routine, rule-based administrative and transactional tasks whilst those requiring relationship management, negotiation, problem-solving, judgement and domain expertise typically will remain (DiRomualdo et al., 2018). Artificial intelligence may boost analytic and decision-making abilities by providing the right information at the right time (Wilson \& Daugherty, 2018).

The challenges brought about by technological innovations should be addressed by complementary and innovative approaches to provide innovative solutions that include radical methods that can be deployed to anticipate emerging technologies and their impact from a holistic perspective (Morrar, Arman, \& Mousa, 2017). McClure (2018) found that there exists a sizable population of 'technophobes' or those who fear robots, AI and technology they do not understand. In the 4IR, there could be retrenchments because of automation processes and the use of robots (Pandian, 2018). Jin (2021) states that the digital transformation of $H R$ is vital in the 4IT and the 5G Era. The HR professional must be a technology integrator (Ulrich, Kryscynski, Ulrich, \& Brockbank, 2017).

Human resource professionals' decision-making could be improved by being data driven. Consulting firms, academics 
and individual HR professionals have examined the basic applications of HR data to create well-functioning HR practices, but HR should rather focus on creating the organisational capabilities that are the foundation of high-performing institutions (Brockbank et al., 2018). The growth of data volumes available for analysis assists with managerial decisions and business intelligence (Gokhberg et al., 2017). It is essential to employ a clear data strategy to produce, capture and refine the data that is necessary for process redesign (Shukla, Wilson, Alter, \& Lavieri, 2017).

Ethical behaviour will remain essential in the future world of work. When ethics and values are sacrificed for superficial benefits, success tends to be limited (Silver, 2018). Ethical leadership further is a manifestation of honesty and credibility, concern, doing the right thing, openness of communication, a personal life based on morality standards and being fair in decision-making, which influences ethical behaviour (Aryati, Sudiro, Hadiwidjaja, \& Noermijati, 2018). In order for HR to be reinvented, its main five stakeholders must receive outcomes that matter to them: employee (productivity and well-being), strategy (direction and execution), customer (net promoter score and customer share), investor (financial results and intangible confidence) and community (reputation) (Ulrich \& Smallwood, 2021).

In the South African context, the reinventing of HR necessitates resilience to assist companies to transform in a fast and positive way (Schultz, 2021). In addition, the rebalancing of priorities and rethinking of HR lead to the fact that resilience becomes equally important to strategic thinking, cost and efficiency (Schultz, 2021). Mefi and Asoba (2021) found that there are technological skill deficiencies amongst South African HR practitioners arising from the transition to industry 4.0. Calitz et al. (2017) highlighted a fear of retrenchment because of changes such as introducing cobots (i.e. collaborative robots). As organisations progress to the future and adapt to new realities, HR practitioners should stay abreast of changes to prepare for the future world of work (Schultz, 2019). One of these challenges is to ensure an updated human resource information systems (Ngwenya et al. 2019). Another challenge is the impact of COVID-19 on employees in the workplace (Bussin \& Swart-Opperman, 2021), which HR practitioners will also need to deal with.

\section{The role of human resources management in the Fourth Industrial Revolution}

'A role is a comprehensive pattern of behaviour that is socially recognised, providing a means of identifying and placing an individual in a society' (Britannica, 2021:online). A role for the purpose of this study is the set of behaviour expected from HR practitioners:

Since the beginning of industrialisation, technological leaps have led to paradigm shifts and have had a strong impact on the functional areas of individual work systems; in retrospect, these changes can be defined as industrial revolutions. (Wilkesmann \& Wilkesmann, 2018, p. 251)
Increased productivity presented the underlying thrust for each industrial revolution ( $\mathrm{Xu}$ et al., 2018). To ensure productivity within HR, it is essential to rethink the role of HR. DiRomualdo et al. (2018) suggested that the HR department needs to rethink roles, for example, which activities can be fully digitised and how existing roles should be redefined. This department should further consider which high-impact areas and existing HR roles currently do not address adequately. The HR manager should coordinate industrial changes, such as automation, including the use of robotics to increase the efficiency of business operation (Pandian, 2018). The HR manager should further assist business leaders in navigating towards the best business decisions, often by means of technology (Hogg, 2019). Human resource faces a once-in-a-lifetime opportunity to be strategic, integrating the business digitisation process whilst assisting the workforce in transitioning to value- and purpose-based employment, instead of previous task- and skill-based employment (Papageorgiou, 2018). During digital transformation, HR departments will have the role of change agents to ensure that the organisation has the capacity for change (Karasek, 2020).

As business strategies and teams grow more agile to keep pace with recurring change in companies, HRM must also adapt (Schultz, 2021) and assist with business transformation (Bersin, 2020). Human resource managers should understand the basic business drivers such as global business, economic growth, capital markets, changing customer behaviour and competition (Thakur, 2020). According to Ulrich et al. (2017), the HR practitioner must be a strategic positioner and be able to position a business to achieve success in its market. Specialising in big data systems, maintenance and the analysis of both HR-specific and enterprise data are required in the digital age (DiRomualdo et al., 2018). Data privacy will be an important issue of HR analytics in the future. As there will be an increasing amount of data available ('big data'), there will be a blurring of lines in using data for business progress. By applying metrics and analytics in all functions of the HR department, management decision-makers can modify comprehensive employment systems by effectively managing the company's human capital (Durai, Rudhramoorthy, \& Sarkar, 2019). By having access to the knowledge and inner workings of all of the best HR data sources, the HR Technology Centre of Expertise (CoE) is an ideal place to focus resources on workforce analytics to drive business insights and recommendations (Fernandez, 2019). As HR departments rush to deploy cloud technologies, robotics process automation and HR analytics, there is a growing need for a CoE dedicated to HR data and technology.

Human-machine collaboration enables companies to interact with employees and customers in novel, enhanced ways (Wilson \& Daugherty, 2018). Legions of data analysts, IT professionals and experts in financial fraud are needed at the interface between humans and machines to guard against criminal interventions (Wilson \& Daugherty, 2018). In working with machines, humans are advised to build machines for specific tasks, to explain their actions to other 
humans and to sustain the quality, safety and ethics of how cobots are used (Wilson \& Daugherty, 2018). Furthermore, the use of cobots in production must be designed in such a way that employees experience the new technology as supportive and not as a rival (Wilkesmann \& Wilkesmann, 2018, p. 247). The HR practitioner should therefore be able to act as a change agent to ensure that employees are appropriately informed about cobots and the further possible impact of 4IR. Being a change agent in the future world of HRM is of utmost importance (Jin, 2021; Ulrich et al., 2017).

In the South African context, business acumen will be a prerequisite to enable and influence the future role of $\mathrm{HR}$ in a positive way (Schultz, 2021). Dhanpat et al. (2021) stated that technical, managerial and soft skills will be critical for competitive advantage in 4IR. The 4IR not only holds changes for the future world of work but it also holds significant threats and opportunities to the relationship between employment relations stakeholders (Mabasa, 2020). Mefi and Asoba (2021) stated that the human-machine interface skills will be essential for South African HR practitioners. Cobots increasingly collaborate with humans in factory production and assembly environments in African organisations (Calitz et al., 2017). Traditional thinking about the workspace will be needed in the future world of work (Schultz, 2021). In conclusion, the HR role within South Africa will have to be improved to meet the demands of the 4IR (Bothma, 2019; Patel, 2019). This may lead to new skills for HR practitioners (Dhanpat et al., 2020; Maisiri \& Van Dyk, 2021). It is interesting to note that a mindset shift for the 4IR will be necessary (Molloy \& Ronnie, 2021).

\section{Research method}

The research design, population and sample, research instrument, data analysis, trustworthiness of the data and the ethical considerations are discussed below.

\section{Research design}

Given that this study surveyed a wide range of participants, a qualitative survey as a research design was used. Braun et al. (2020) stated that this type of survey can harness the rich potential of qualitative data but seems to be underutilised. The qualitative type of survey does not aim at establishing frequencies, means or other parameters but at determining the diversity of some topic of interest within a given population. This type of survey does not count the number of people with the same characteristic (value of variable), but it establishes the meaningful variation (relevant dimensions and values) within that population by studying the diversity in a population (Jansen, 2010). Openended questions were utilised to collect data.

\section{Population and sample}

Members who are affiliated with the South African Board of People Practices (SABPP) formed the population of this study (4500 members). Those members of the SABPP who were employed as HR practitioners in the private and public sector and not in academe were invited to participate in the study.
The reason for this inclusion criterion was that active involvement in the field was deemed more pertinent than academic knowledge in this study. A total of 108 members volunteered to participate in the study. Considering the present study's focus on the future, as well as the type of data collection technique used, all participants were included in order to obtain rich data about the future of HRM. After analysing the input of participant 105, saturation of data was reached. No new information and views were therefore produced. The answers of the participants were very short and that is why the number of participants was more than in a usual qualitative face-to-face interview setup. Each of the 105 participants wrote on average 34 words. This provided a clear indication of the vastness of participants' views about the future of HRM. Finally, 42 males and 66 females participated, including 61 participants from the private sector and 47 participants from the public sector. The age range was between 25 and 65 years.

\section{Research instrument}

Data were collected by means of an open-ended questionnaire to obtain rich data from participants. The following three open-ended questions were sent to participants by means of a SurveyMonkey link:

- What are your views about the future of HRM?

- What is the role of HRM in the Fourth Industrial Revolution?

- In your opinion, which areas of development are essential to prepare HRM for the future world of work?

For the purpose of this article, only the first two questions were analysed and reported upon because they are related to the study purpose. As a result of a qualitative survey as a research design, SurveyMonkey was used to collect the data.

\section{Data analysis}

The data were organised into Excel spreadsheets in a way that facilitates analysis. The researcher followed the thematic analysis approach to analyse the data collected (Tesch, 1990). This involved searching for phrases and words that appeared to be the same based on the literature on the future of HRM. Simple colour coding was used to identify themes (Skjott Linneberg \& Korsgaard, 2019). The main themes were identified, which led to the conclusion and recommendations. Thematic analysis allowed for data to be presented in words and themes and also allowed for easy interpretation of the findings (Bengtsson, 2016). This type of analysis enabled the meaning and interpretation of the data whereby the researcher allocated codes and assigned themes to the collected data (Neuendorf, 2019). The text was allocated appropriate labels, themes, codes and categories in alignment with the research objectives of the study (Bazeley, 2013).

A combination of inductive and deductive coding is the most commonly used approach, what is sometimes referred to as a blended approach (Graebner, Martin, \& Roundy, 2012) or abduction (Alvesson \& Kärreman, 2007). There is a strong 
tradition in qualitative research of developing codes 'directly' from the data. The researcher developed codes from the data by using phrases or terms used by the participants themselves, rather than using the, often theoretical, vocabulary of the researcher. In this way, the codes stayed close to the data, mirroring what is actually in them, rather than the ideas and prior understandings of the researcher, who is working vigorously to remain open minded (Skjott Linneberg \& Korsgaard, 2019). This approach is most often referred to as the inductive approach. Generally, the codes in deductive coding are theoretical concepts or themes drawn from the existing literature. The following main literature was used for deductive coding: Brockbank et al. (2018), Silver (2018), Wilkesmann and Wilkesmann (2018) and Calitz et al. (2017).

\section{Trustworthiness of the data}

Trustworthiness involves the following elements: credibility, dependability, confirmability and transferability (Bless, Higson-Smith, \& Sithole, 2013). In the present study, credibility was established through peer debriefing and member checks (Madill \& Sullivan, 2018). Peer debriefing was performed involving a disinterested peer - a peer who is not involved in the research project - to aid in probing the researcher's thinking around all or parts of the research process. Member checking was not carried out because of the fact that a brief summary of the findings or sharing the whole findings was not shared with the research participants because of the data collection technique. The study used a transparent process of coding to ensure that the research process was logical, traceable and clearly documented to ensure dependability (Sinkovics \& Alfoldi, 2012). According to Zhang and Wildemuth (2009), confirmability is determined by checking the internal consistency of the research product. In the present research, this was achieved by ensuring that the data are available so that other researchers or reviewers can access or audit it to ensure that the results were not fabricated.

\section{Ethical considerations}

Permission to conduct this study was obtained from the SABPP. Ethical permission was obtained from the Research Ethics Committee of the Tshwane University of Technology (Pretoria Campus), Ref\#: FCRE2018/FR/10/025-MS. The researcher adhered to essential ethical standards in all aspects of the research process. All possible participants received an overview of the study, before inviting them to participate voluntarily. As a result of the nature of the qualitative survey, participants were assured of the anonymity and confidentiality of their responses by using SurveyMonkey. They were also informed that they could withdraw from the study at any stage, if they wish. All participants indicated their consent to participate in the study after accessing the relevant information by means of the SurveyMonkey link.

\section{Findings}

The data revealed nuanced details about the future and the role of HRM in South Africa. The following themes were identified: technology-driven, data-driven, ethically driven, change driven, business-driven, human-machine collaboration and presilience. Please note that all quotes are reproduced verbatim and unedited.

\section{Theme 1: Technology driven}

In order for the HR practitioners to thrive in the 4IR, their focus should be on technology in order driven to support business results as seen by Participant 31:

'Stay relevant and enable business results through technology and digitisation.' (Participant 31, male, public sector)

If HR practitioners are not technology driven, business results and other HR processes may not be effective and efficient. Participants 24 and 104 were of the opinion that it is essential to automate HR processes by means of digitisation:

'I do believe that HR of the future is digitally based, less paper, more data and informatics to guide business decisions where people are concerned.' (Participant 24, female, public sector)

'All areas in HR should be digitalised and consider millennials in what we do.' (Participant 104, female, public sector)

An important issue that surfaced is the fact that technology creates fear amongst employees. Technophobes are those who fear robots, AI and technology, and according to Participant 27, they are a reality in South African organisations:

'HR will be more challenging than ever. Technology advances but workers see it as a threat.' (Participant 27, female, public sector)

Technophobes are also threatened because of possible job losses. It is therefore crucial that HR practitioners reduce such fears by providing awareness campaigns and relevant technology-related training to all employees. Human resource practitioners should also engage constantly with employees in order to allow employees to verbalise and deal with their fears in a constructive manner. This is a prominent role of HR practitioners in the 4IR:

'The advancement of technology is threatening jobs security.' (Participant 30, female, public sector)

'HR has to focus more on motivating employees in view of the Fourth Industrial Revolution. People fear losing jobs, so HR plays a vital role in helping people develop new skills.' (Participant 55, female, public sector)

In order to successfully deal with technophobes, it will be essential that HR practitioners assist management in creating an environment conducive to alleviating employees' fears. Such an environment will assist employees to positively embrace technology:

'Positive work environment that does not create fear amongst employee due to technology.' (Participant 23, male, private sector)

It is evident that HRM should drive technology to support business results, but this might create fear among employees. Human resource management should therefore create a positive work environment and ensure that employees do not feel threatened and rather embrace technology. 


\section{Theme 2: Data driven}

It is essential that HR practitioners and HR managers must make informed business decisions in their role as business partners. One way in doing this is to use technological, qualitative, intelligent data to make such informed business decisions. The fact that people data should be readily available is something that HRM should take serious note of. The understanding and dealing with data analytics are therefore inevitable. An important role of HR in the 4IR will be to employ data analytics in making proper business decisions:

'The HR function is also becoming data-driven. Data analytics is playing a big role in helping HR leaders make informed decisions.' (Participant 70, female, private sector)

'Ensuring that people data is readily available for business decisions.' (Participant 77, female, private sector)

'High tech, qualitative, intelligent provision of data analytics for business decision-making.' (Participant 10, female, private sector)

There was a strong sense amongst the participants that data could also be used to improve people and business practices and lead to life-changing practices. It is therefore important that HR practitioners should see data as influential in their role in the 4IR:

'Providing data to improve people practices which will improve business practices, which will improve our countries' economy. Transforming influential data into life-changing practices.' (Participant 105, male, public sector)

Human resource practitioners sometimes shy away from numbers, but the ability to deal with numbers in the future workplace is essential because it will rely on data analytics to assist with business decision-making and to provide information about staff issues.

\section{Theme 3: Ethically driven}

The ethical behaviour of HR professionals is crucial in the future world of work. To ethically driven is a non-negotiable in the 4IR. According to Participant 35, an HR professional needs good ethics:

'It needs professionals that has good ethics.' (Participant 35, male, public sector)

In the same vein as ethics, the African concept of $u b u n t u$ was also mentioned. Ubuntu was developed by conducting inductive coding. Ubuntu is a term meaning 'humanity' and is often translated as 'I am because we are' or 'humanity towards others' (Gade, 2011). Ubuntu as African humanism, is a philosophy, an ethic and a worldview (Gade, 2011). Since the transition to democracy in South Africa with the Nelson Mandela presidency in 1994, the term has become more widely known outside of Southern Africa:

'Future of HR is on the rise with principles of ubuntu and ethical behaviour being a necessity.' (Participant 29, male, private sector)

Through HRM, ethics can be given credibility and aligned with how businesses and HR practices are executed. It is important to understand that ethical behaviour is rooted within a person, and HRM should therefore be self-driven and dynamic by portraying their own ethics and encourage others to also be ethically driven. Complying with legislation is a further dimension and requirement of ethics in the workplace and HR should therefore adhere to what is right:

'HR needs to be dynamic and self-driven by being ethical.' (Participant 62, male, private sector)

'All the HR employees must comply with the legislation do what is right and be an example to other employees.' (Participant 64, female, public sector)

Ethical behaviour and the humanity of HR professions are crucial in the future world of work. Therefore, HR professionals should ensure that they are self-driven and dynamic and that they comply with legislation in order to do what is right.

\section{Theme 4: Change driven}

Change is inevitable in the future, and HR professionals need to be able to adapt to change. It is important for HRM to be change driven in order to build relationships of trust and respect and not to neglect these relationships:

'HR needs to be able to adapt to changes and be able to innovate.' (Participant 36, female, public sector)

'Support, embrace the change and ensure business is prepared for the rapid rate of change, without losing the opportunity to build sound relationships of trust and respect.' (Participant 44, female, private sector)

Human resource professionals should take cognisance of the fact that changes relating to employee-employer relations should be addressed and that they themselves stay relevant in the future workplace. In building these relationships, HR professionals should assist employees in coping with the swift changes related to the future workplace:

'To help people cope with the anticipated rapid rate of change.' (Participant 68, male, public sector)

The ability to adapt to change, build essential relationships of trust and respect, assist employees in coping and address employee-employer relationships are important aspects that the HR professional should focus on to stay relevant in the future. The fact that the HR practitioner should be change driven requires HRM to lead change and be a leader:

'To be change ambassadors and lead the change process in the organisation.' (Participant 45, female, public sector)

'To ensure that personnel are engaged given the changes taken place because of the revolution.' (Participant 28, male, private sector)

Becoming change driven, entails more than merely being a change agent because HRM needs to both lead change and engage with staff to facilitate change. In the 4IR, change must be driven by HR practitioners because of the fact that it will be expected from them by management and employees. 


\section{Theme 5: Business driven}

An important role of $\mathrm{HR}$ in the 4IR is to enable the organisation - including its employees - to be ready. The business should be prepared for, changes, skills development and data management. This will be made possible if HR practitioners possess critical and strategic thinking skills in order to enable the business for readiness and be business driven:

'Ensure that the business is ready for the changes in the world, skills development and data management.' (Participant 24, male, public sector)

'To be a critical and strategical thinker.' (Participant 34, female, private sector)

Advanced systems and alignment to the best practices of the business form part of HRM in enabling the business in the 4IR. Jobs will need to be redesigned, and people will need to be reorganised to meet future demands and to deal with technological changes:

'Business enablement with advanced systems and alignment to the industry best practices.' (Participant 3, male, public sector)

'Redesigning jobs to meet the future demands.' (Participant 96, female, public sector)

'Re-organising people and their talent to respond to technological changes.' (Participant 37, female, private sector)

In order to be business driven in the 4IR, a critical role of HRM will be to drive the organisation to become a learning organisation, to drive innovation and to oversee continuous improvement. Human resource management can understandably not do this in silos and should therefore create an awareness through constant engagement with management and employees:

'To drive the organisation being a learning organisation, to drive innovation and continuous improvement.' (Participant 17, female, public sector)

In order to enable the business to be successful, HR practitioners should assist with preparing future readiness that entails change, skills development and data management. Human resource practitioners should be critical and strategic thinkers in order to properly enable the business to be prepared for the future world of work. Aligning systems, developing best practices, supporting staff to adjust, redesigning jobs and reorganising people also are essential parts of the role of $\mathrm{HR}$. Human resource should drive a business to become a learning organisation and continually drive innovation and improvement to enable the business to be successful in the 4IR.

\section{Sub-theme 6: Human-machine collaboration}

The human side of an organisation should never be neglected in dealing with $\mathrm{AI}$, and $\mathrm{HR}$ therefore has a significant role to play:

'To adapt to the technology without losing the human touch.' (Participant 5, female, public sector)

'Invest in technology but don't forget about the human element in the organisation.' (Participant 42, female, private sector)
Human resource will have to alert employees to improve their creativity and cultivate a culture where humans and machines can interact in a positive manner to reduce employees' perceptions of the possible threats that machines hold:

'It is going to be great, driven by robotics, artificial intelligence and humans dealing with creativity and human interactions instead of mechanical processes.' (Participant 68, male, public sector)

'Finding a way to promote the interactions between humans and non-humans in a manner that will not be perceived as a threat to human resources.' (Participant 83, male, private sector)

Human resource must provide the necessary attention to the human side and positive interaction in collaborating with machines in the workplace. In doing so, HR will act as a type of a convener who will be responsible for bringing employees, management and the inventors or developers of machines together to address issues, problems and opportunities. In the context of human-machine collaboration, it will involve convening representatives from multiple sections in an organisational and a multi-meeting process, on this complex issue.

\section{Theme 7: Presilience}

Presilience as a theme was developed through inductive coding. Schneider and Mcquirk (2020) opined that:

$[P]$ resilience is about flexibility in responding to the risks of the future, and given the scale and pace of major events over recent months - driven by climate change and an increased global movement of people - we need to get better at responding to what is unfolding in front of us, that is, insight - not just concentrate on avoiding the mistakes of the past, that is, hindsight. (p. 1)

Schneider and Mcquirk (2020:1) also stated that presilience focuses on building the mental endurance, across the whole organisation not only to 'bounce back' but also to completely avoid crises, manage them effectively and minimise any negative effects - ideally it represents the idea of 'bouncing back better.' Essentially, presilience entails risk intelligence, agility and flexibility. Flexibility by itself is not sufficient; HR should also be agile:

'Flexibility and continuous learning will play an important role in catapulting HR performance to the next level.' (Participant 56, female, private sector)

'HR needs to evolve with the Fourth Industrial Revolution, be more agile and utilise artificial intelligence.' (Participant 12, female, public sector)

Human resource needs to be reinvented by thinking about and doing things in a new manner and by continually obtaining the necessary skills and learning. Flexibility and agility are necessary for supporting organisational strategy and to drive organisational performance through people. To stay relevant, HR should measure its performance against the financial success of the business, ensure that the needs of employees, management and the organisation are met and act as the custodian of equality and fairness. Redefining the future world of work necessitates HR to capacitate staff to remain relevant in terms of what the organisation needs: 
'Train and capacitate employees so that they continue to remain relevant.' (Participant 15, male, private sector)

'Advising and shaping employees to be what the organisation needs and not just employing dead weight.' (Participant 20, female, public sector)

In order for HR to capacitate employees properly, a new mindset, adaptability, flexibility and agility will be essential, in order to embrace continuous disruption:

'To develop employees to do better and have a different mindset. Get people ready to embrace continuous disruption.' (Participant 41, male, public sector)

'Helping people develop adaptability, flexibility and agility.' (Participant 41, male, public sector)

A part of being presilient in the 4IR, an HR role that might be challenging is to alleviate unemployment, inequality and poverty through training and development, especially in a developing country, such as South Africa:

'Training and development towards alleviation of unemployment, inequality and poverty.' (Participant 26, male, private sector)

The main reason why HR needs to capacitate employees is to assist them in remaining relevant and to have presilience. The new focus is on the people who are managing and responding to risk and presilience is about enhancing their inherent skills and capabilities to be adaptable, flexible and agile in response and then building the systems to support them as opposed to making them fit into the system. Presilience is the attribute and process of successfully preventing where possible, preparing for, responding to and recovering from adverse, major business interruption events and crises whilst looking for opportunities. Unlike resilience, which focuses purely on recovery and the ability to 'bounce-back', presilience focuses on building the mental fortitude, across the whole organisation not only to 'bounce back' but also to completely avoid crises, manage them effectively and minimise any negative effects - ideally it epitomises the idea of 'bouncing back better.' Presilience is much more than simply being reliable and ensuring business continuity in case a negative event happens, it's about high performance and outcomes to ensure better performance. It's about constant learning and adaption to seize opportunity, not simply recovering from a negative event. Presilience focuses on leaders and teams applying high-level critical reasoning skills to the problem in front of them, quickly developing a plan, making effective decisions within a simple framework and executing effective action through clear, effective and directive communication (Schneider \& Mcquirk, 2020:1). A challenging role for HR is that of alleviating unemployment, inequality and poverty through training and development.

\section{Discussions}

The purpose of this study was to investigate the future and the role (or set of behaviours) of HRM in South Africa during the 4IR. It is evident that the future of HR will be technology driven to support business results. It is essential that existing HR processes have to be automated through digitisation. This study concurs with Papageorgiou's (2018) suggestion that digitisation and assisting the workforce in transitioning to value- and purpose-based employment are important features of the future of HR. It is critical that HR has insight into new technologies and their disruptive potential especially in developing countries. This suggestion corresponds to the South African finding of Mefi and Asoba (2021), Xu et al. (2018) and Ulrich et al. (2017) who also found that HRM must be technology driven. Technology may generate fear amongst employees, and they may feel threatened because of the possibility of losing their jobs. Human resource managers and HR practitioners should therefore assist management in creating an environment that reduces employees' fears. This supports the findings of Wilkesmann and Wilkesmann (2018). Calitz et al. (2017) described the fear of retrenchment because of cobots in the African and South African context. Data should serve to assist management in making informed business decisions to plan ahead and improve people and business practices, concurring with the study of Durai et al. (2019) who also found that HR must be data driven. As evident from the findings of the present study, the ethical behaviour of HR professionals is crucial in the future world of work. Human resource professionals should therefore be self-driven and dynamic by portraying ethics. Complying with legislation in the workplace is also an important part of ethics, requiring HR professionals to do what is right. Aryati et al. (2018) also found that ethical behaviour will be a prominent future area. Human resource professionals must therefore be able to adapt to change and build relationships of trust and respect during the process. In building these relationships, HR professionals should assist employees in coping with the swift changes related to the future workplace. Change relating to employee-employer relations also forms an important part of staying relevant in the future workplace. Pandian (2018) also highlighted the importance of adjusting and staying relevant in the new world of work.

Human resource needs to be reinvented by thinking about and doing things in a new presilient manner. To achieve this, HR needs to possess the necessary skills, by focusing on learning continuously and being flexible. Flexibility by itself, however, is not sufficient; HR also needs to be agile. Whilst reinventing $\mathrm{HR}$, overall $\mathrm{HR}$ should support the organisational strategy. In supporting the organisational strategy, HR professionals should drive organisational performance through people. In addition, HR should consider that his or her own performance will be measured against financial success to ensure remaining relevant. When determining the efficiency of HR, it is important to ensure that the needs of employees, management and the organisation have been met. In meeting the needs of people and the organisation, it will be the duty of HR to be the custodian of equality and fairness. DiRomualdo et al. (2018), for instance, found that HR needs to rethink its role. It is vital that the HRM department has the ability to transform in the 4IR (Bissola \& Imperatori, 2018; Karasek, 2020). 
An important role of HR is to enable the organisation including the employees - to be ready for the 4IR. An HR practitioner should be a critical and strategic thinker to enable the business for readiness. Advanced systems and alignment to the business' best practices also form part of HRM in enabling the business. Another important role of HR is to support management and employees in revising their ways of working in order to handle the future of work. Jobs will need to be redesigned and people will need to be reorganised to meet the future demands and deal with technological changes. A critical role of HR will be to drive the business to become a learning organisation, to drive innovation and to oversee continuous improvement. Hogg (2019) found that HR must assist business leaders towards making the best business decisions, often with the use of technology. An important role of HR in the 4IR will be to use data analytics to guide business decisions. Considering that HR will need to provide information on staff issues, an ability to use HR analytics would therefore be essential. Human resource will have to focus on numbers in the future workplace, because they will need to employ data analytics to assist with business decision-making and to provide information about staff issues. Previous research also highlighted the importance of data analytics (Fernandez, 2019; Shukla et al., 2017; Ulrich et al., 2017), whilst Van den Heuvel and Bondarouk (2017) and Rajbhar, Khan and Puskar (2017) emphasised the importance of data analytics in transformation. To capacitate employees, HR professionals need to remain relevant in terms of what the organisation needs. In order for HRM to capacitate employees properly, a new mindset, adaptability, flexibility and agility will be essential in order to embrace continuous disruption. Once this is achieved, performance can be increased through digital engagement.

An HR role that might be challenging is to alleviate unemployment, inequality and poverty through training and development, especially in a developing country such as South Africa. Human-machine collaboration was an important sub-theme in this study. In dealing with AI, HRM has a significant role in seeing to it that the human side of an organisation is never neglected. Human resource management will have to make employees aware of the fact that they should improve their creativity and cultivate a culture where humans and machines can interact in a positive manner to lessen employees' perceptions of the possible threat of machines. Fears of technology exacerbate fears of unemployment and financial insecurity. Technophobes are also more likely than nontechnophobes to report having anxiety-related mental health issues and to fear unemployment and financial insecurity (McClure, 2018). According to Gikopoulos (2019), there is a fine balance between man and machine, and whilst technology will increase efficiency and improve the value of HR in businesses, the human touch will always be the key to success, corresponding to the findings of the present study. Wilkesmann and Wilkesmann (2018) also emphasised that cobots could assist during production, as well as assist employees, and they should therefore not be seen as adversaries. The HR practitioner will have to become an ambassador of change and this finding corresponds with the finding of Ulrich et al.'s (2017). Becoming an ambassador of change entails more than merely being a change agent, because HR needs to lead change and engage with staff to facilitate change. Human resource practitioners find themselves in a unique position at the outset of the 4IR era because they are in the front line of advising organisations about the best ways to address the forthcoming change (Schultz, 2021).

\section{Practical implications}

In terms of the future of HR, outdated human development strategies that focus mainly on the acquisition of knowledge, should be replaced with finding talented individuals who are able to apply existing knowledge, create new ideas and learn from trial and error (Lee, 2017). To support the future of organisations, HR will be tasked with the complete integration of people and technology, taking a holistic approach to organisational and technological transformation at a previously unimagined scale. A culture that empowers employees to thrive alongside intelligent machines whilst encouraging workers to maintain a healthy scepticism of machine-generated outcomes must be developed (Shukla et al., 2017).

The role of $\mathrm{HR}$ in the 4IR offers both challenges and opportunities in terms of advancing the technological capabilities of the workforce to ensure that it keeps up with technological advancement, as well as ensuring an organisation is equipped to deal with the unknown. From a managerial perspective, suitable investment in IT systems is necessary, as well as the upgrading of systems and establishing a solid infrastructure for data collection, data analysis and prediction. If HR practitioners are not technology driven, data driven, ethically driven, change driven, business driven, human-machine collaboration and presilient, they may have difficulty to add value to the organisation in the 4 IIR.

\section{Limitations, recommendations and future research ideas}

The present study had some limitations, and therefore, the findings should be approached with caution. Firstly, whereas a single study approach facilitated a rich investigation of the future of HRM, the theory that I derived from this investigation may be limited in its generality. Secondly, only members of one professional body participated and the views of additional HR practitioners in South Africa were not obtained. Lastly, as SurveyMonkey was used during data collection, it was not possible to follow up on participants' views. Member checking was therefore not performed.

It is evident that for the future of $\mathrm{HR}$, managers should align their workforce strategy with their business strategy, to allow for the mobility and flexibility that cobot solutions provide, to create a sustainable work environment of the future (Calitz et al., 2017). It is important to alleviate the fear that employees 
may experience because of possible retrenchments because of automation. Redesigning jobs to embrace the interaction between human employees and machines and allowing both to perform roles most suited to their unique set of abilities are essential (Shukla et al., 2017). Companies need employees who continually work to ensure that AI systems are functioning properly, safely and responsibly (Wilson \& Daugherty, 2018).

Furthermore, for HRM to function optimally during the 4IR, management should decide whether to invest in an HR analytical team based within the HR function or to set up a centralised analytics team covering all disciplines, which would be more cost effective (Van den Heuvel \& Bondarouk, 2017). A manager's decision-making behaviour could be changed by reporting HR indicators, using a return on an investment-based approach that is based on metrics and analytics (Durai et al., 2019).

A possible direction for future research is to duplicate the present research in other countries to determine the future of $\mathrm{HR}$, as well as the role of HR practitioners in the 4IR entail in their contexts. A further research idea might be to develop a questionnaire that is based on the findings of the present study to conduct a quantitative study about the future of HR. With such a quantitative approach, different variables that influence the future of $\mathrm{HR}$ could be identified.

\section{Acknowledgements Competing interests}

The author declares that they have no financial or personal relationships that may have inappropriately influenced them in writing this article.

\section{Author's contributions}

C.M.S. is the sole author of this article.

\section{Funding information}

This work was supported by the National Research Foundation of South Africa under grant number TK150621119893 and by the Niche Area of the future of work and the alleviation of unemployment and poverty' within the Faculty Management Sciences of the Tshwane University of Technology.

\section{Data availability}

The author confirms that the data supporting the findings of this study are available within the article.

\section{Disclaimer}

The views and opinions expressed in this article are those of the author and do not necessarily reflect the official policy or position of any affiliated agency of the author.

\section{References}

Alvesson, M., \& Kärreman, D. (2007). Constructing mystery: Empirical matters in theory development. Academy of Management Review, 32(4), 1265-1281. https://doi.org/10.5465/amr.2007.26586822

Aryati, A.S., Sudiro, A., Hadiwidjaja, D., \& Noermijati, N. (2018). The influence of ethical leadership to deviant workplace behavior mediated by ethical climate and organizational commitment. International Journal of Law and Management, 60(2), 233-249. https://doi.org/10.1108/IJLMA-03-2017-0053

Ayentimi, D.T., \& Burgess, J. (2019). Is the fourth industrial revolution relevant to subSahara Africa? Technology Analysis \& Strategic Management, 31(6), 641-652. https://doi.org/10.1080/09537325.2018.1542129

Bazeley, P. (2013). Qualitative data analysis: Practical strategies. London: Sage.

Bengtsson, M. (2016). How to plan and perform a qualitative study using content analysis. Nursing Plus Open, 2, 8-14. https://doi.org/10.1016/j.npls.2016.01.001

Bersin, J. (2020). Introducing resilient HR: A New way to run your business. Retrieved from https://joshbersin.com/2020/09/introducing-resilient-hr-a-new-way-torun-your-business/

Bissola, R., \& Imperatori, B. (2018). HRM 4.0: The digital transformation of the HR department. In F. Cantoni \& G. Mangia (Eds.), Human resource management and digitalization: The effects of Industry 4.0 on human resources (pp. 51-69). Abingdon-on-Thames: Routledge.

Bless, C., Higson-Smith, C., \& Sithole, S.L. (2013). Fundamentals of social research methods: An African perspective (5th ed.). Cape Town: Juta.

Bothma, R. (2019). HR, get ready for the 4th Industrial Revolution! HR Future, 8 , 40-41.

Braun, V., Clarke, V., Boulton, E., Davey, L., \& McEvoy, C. (2020). The online survey as a qualitative research tool. International Journal of Social Research Methodology, 1-14. https://doi.org/10.1080/13645579.2020.1805550

Britannica. (2021). Role. Retrieved from https://www.britannica.com/topic/role

Brockbank, W., Ulrich, D., Kryscynski, D.G., \& Ulrich, M. (2018). The future of HR and information capability. Strategic HR Review, 17(1), 3-10. https://doi.org/10.1108/ SHR-11-2017-0080

Bussin, M.H.R., \& Swart-Opperman, C. (2021). COVID-19: Considering impacts to employees and the workplace. SA Journal of Human Resource Management/SA Tydskrif vir Menslikehulpbronbestuur, 19, a1384. https://doi.org/10.4102/sajhrm. v19i0.1384

Calitz, A.P., Poisat, P., \& Cullen, M. (2017). The future African workplace: The use of collaborative robots in manufacturing. South African Journal of Human Resource Management, 15, a901. https://doi.org/10.4102/sajhrm.v15i0.901

Dhanpat, N., Buthelezi, Z.P., Joe, M.R., Maphela, T.V., \& Shongwe, N. (2020). Industry 4.0: The role of human resource professionals. SA Journal of Human Resource Management/SA Tydskrif vir Menslikehulpbronbestuur, 18, a1302. https://doi. org/10.4102/sajhrm.v18i0.1302

DiRomualdo, A., El-Khoury, D., \& Girimonte, F. (2018). HR in the digital age: How digital technology will change HR's organization structure, processes and roles. Strategic HR Review, 17(5), 234-242. https://doi.org/10.1108/SHR-08-2018-0074

Durai, S.D., Rudhramoorthy, K., \& Sarkar, S. (2019). HR metrics and workforce analytics: It is a journey, not a destination. Human Resource Management International Digest, 27(1), 4-6. https://doi.org/10.1108/HRMID-08-2018-0167

Fernandez, J. (2019). The ball of wax we call HR analytics. Strategic HR Review, 18(1), 21-25. https://doi.org/10.1108/SHR-09-2018-0077

Gade, C.B.N. (2011). The historical development of the written discourses on Ubuntu. South African Journal of Philosophy, 30(3), 303-329. https://doi.org/10.4314/ sajpem.v30i3.69578. S2CID 143928483.

Gikopoulos, J. (2019). Alongside, not against: Balancing man with machine in the HR function. Strategic HR Review, 182, 56-61. https://doi.org/10.1108/SHR-12-20180103

Gokhberg, L., Sokolov, A., \& Chulok, A. (2017). Russian S\&T Foresight 2030: Identifying new drivers of growth. Foresight, 19(5), 441-456. https://doi.org/10.1108/FS-072017-0029

Graebner, M.E., Martin, J.A., \& Roundy, P.T. (2012). Qualitative data: Cooking without a recipe. Strategic Organization, 10(3), 276-284. https://doi.org/10. $1177 / 1476127012452821$

Hogg, P. (2019). Artificial intelligence: HR friend or foe? Strategic HR Review, 18(2), 47-51. https://doi.org/10.1108/SHR-11-2018-0094

Jansen, H. (2010). The logic of qualitative survey research and its position in the field of social research methods. Forum Qualitative Sozialforschung/Forum: Qualitative Social Research, 11(2), Art 11, 1-21.

Jin, L.J. (2021). Methods, stages and misunderstandings of digital transformation of HR management. In XV International conference 'Russian regions in the focus of changes' (ICRRFC), 12-14 November 2020 (pp. 82-88). Ekaterinburg, Russia.

Kapoor, B., \& Sherif, J. (2012). Global human resources (HR) information systems. Kybernetes, 41(1/2), 229-238. https://doi.org/10.1108/03684921211213052

Karasek, A. (2020). HR roles - The state-of-the-art and challenges. Scientific Papers of Silesian University of Technology. Organization and Management Series, 315-325. https://doi.org/10.29119/1641-3466.2020.149.27

Lee, S. (2017). Developing creative human resources for the preparation of the Fourth Industrial Revolution. Association for Talent Development. Retrieved from https:// www.td.org/insights/developing-creative-human-resources-for-the-preparationof-the-fourth-industrial-revolution 
Mabasa F.D. (2020). Fourth Industrial Revolution: Threat and opportunity on employment relations. The 5th Annual International Conference on Public Administration and Development Alternatives, 07-09 October 2020. Retrieved from $\mathrm{http}: / /$ /hdl.handle.net/10386/3233

Madill, A., \& Sullivan, P. (2018). Mirrors, portraits, and member checking: Managing difficult moments of knowledge exchange in the social sciences. Qualitative Psychology, 5(3), 321-339. https://doi.org/10.1037/qup0000089

Maisiri, W., \& Van Dyk, L. (2021). Industry 4.0 skills: A perspective of the South African manufacturing industry. SA Journal of Human Resource Management/SA Tydskrif vir Menslikehulpbronbestuur, 19, a1416. https://doi.org/10.4102/sajhrm.v19i0.1416

McClure, P.K. (2018). "You're Fired," Says the Robot: The rise of automation in the workplace, technophobes, and fears of unemployment. Social Science Computer Review, 36(2), 139-156. https://doi.org/10.1177/0894439317698637

Mefi, N.P., \& Asoba, S.N. (2021). Industry 4.0 and skills deficiencies in the HRM function: Case study of the HRM department of a selected organisation in Cape Town. Academy of Entrepreneurial Journal, 27(2), 1-9.

Molloy, L., \& Ronnie, L.C. (2021). Mindset shifts for the Fourth Industrial Revolution Insights from the life insurance sector. SA Journal of Human Resource Management/SA Tydskrif vir Menslikehulpbronbestuur, 19, a1543. https://doi org/10.4102/sajhrm.v19i0.1543

Morrar, R., Arman, H., \& Mousa, S. (2017). The Fourth Industrial Revolution (Industry 4.0): A social innovation perspective. Technology Innovation Management Review, 7(11), 12-20. https://doi.org/10.22215/timreview/1117

Neuendorf, K.A. (2019). Content analysis and thematic analysis. In P. Brough (Ed.), Research methods for applied psychologists: Design, analysis and reporting (pp. 211-223). New York, NY: Routledge.

Ngwenya, L., Aigbavboa, C., \& Thwala, W. (2019). Benefits of human resource information systems in a South African construction organisation. In IOP conference series: Materials science and engineering, 15-16 October 2018 (p. 640). Solo Paragon Hotel, Indonesia.

Pandian, S.S. (2018). Impact of fourth industrial revolution in human resource management. International Journal for Research Trends and Innovation, 3(2), 59-61.

Papageorgiou, D. (2018). Transforming the HR function through robotic process automation. Benefits Quarterly, 34(2), 27-30.

Patel, A. (2019). HR must prepare for the 4IR. HR Future, 1, 8-9.

Pietersen, C. (2018). Research trends in the South African Journal of Human Resource Management. South African Journal of Human Resource Management/SA Tydskrif vir Menslikehulpbronbestuur, 16, a825. https://doi:10.4102/sajhrm.v16i0.825

Rajbhar, A.K., Khan, T., \& Puskar, S. (2017). A study on HR analytics transforming human resource management. Journal of Investment and Management, 6(4), 92-96. https://doi.org/10.11648/j.jim.20170604.12

Schneider, G., \& Mcquirk, T. (2020). The move towards presilience. Retrieved from https://www.ifsecglobal.com/security/the-move-towards-presilience/

Schultz, C.M. (2019). Future expectations from human resource managers: A qualitative perspective. International Journal of Management and Applied Science, 5(9), 6-9.

Schultz, C.M. (2021). The future of HR [Online First]. In G. Sánchez-Gardey, F. Martín Alcázar, \& N. García-Carbonell (Eds.), Beyond human resources - Research path towards a new understanding of workforce management within organizations. IntechOpen. Retrieved from https://www.intechopen.com/online-first/thefuture-of-hr
Shukla, P., Wilson, H.J., Alter, A., \& Lavieri, D. (2017). Machine reengineering: Robots and people working smarter together. Strategy \& Leadership, 45(6), 50-54. https://doi.org/10.1108/SL-09-2017-0089

Silver, W. (2018). The future of HR is being BRAVE. Strategic HR Review, 17(4), 186-192. https://doi.org/10.1108/SHR-05-2018-0043

Sinkovics, R.R., \& Alfoldi, E.A. (2012). Progressive focusing and trustworthiness in qualitative research: The enabling role of computer-assisted qualitative data analysis software (CAQDAS). Management International Review, 52(6), 817-845. https://doi.org/10.1007/s11575-012-0140-5

Skjott Linneberg, M., \& Korsgaard, S. (2019). Coding qualitative data: A synthesis guiding the novice. Qualitative Research Journal, 19(3), 259-270. https://doi. org/10.1108/QRJ-12-2018-0012

Thakur R. (2020) HR in 2020 and beyond: What the future of HR holds. Retrieved from https://www.peoplemattersglobal.com/blog/strategic-hr/hr-in-2020-andbeyond-what-the-future-of-hr-holds-24636

Tarry, A. (2018). The role of HR in the 4th Industrial Revolution. The HR Director Retrieved from https://www.thehrdirector.com/features/revolution/role-hrindustrial-revolution/

Tesch R. (1990). Qualitative research: Analysis types and software tools. Bristol, PA: Falmer.

Thomas, S., Kureshi, S., Suggala, S., \& Mendonca, V. (2020). HRM 4.0 and the shifting landscape of employer branding. In P. Kumar, A. Agrawal \& P. Budhwar (Eds.), Human \& technological resource management (HTRM): New insights into revolution 4.0 (pp. 37-51). Bingley: Emerald Publishing Limited. https://doi. org/10.1108/978-1-83867-223-220201003

Ulrich, D., Kryscynski, D., Ulrich, M., \& Brockbank, W. (2017). Victory through organization: Why the war for talent is failing your company and what you can do about it. The RBL Group. Retrieved from https://www.rbl.net/insights/books/ victory-through-organization-why-the-war-for-talent-is-failing-your-companyand-what-you-can-do-about-it

Ulrich, D., \& Smallwood, N. (2021). HR's Reinvention: Moving from benchmarking and best practices to guidance. Retrieved from https://www.rbl.net/insights/articles/ hrs-reinvention-moving-from-benchmarking-and-best-practices-to-guidance

Van den Heuvel, S., \& Bondarouk, T. (2017). The rise (and fall?) of HR analytics: A study into the future application, value, structure, and system support. Journal of Organizational Effectiveness: People and Performance, 4(2), 157-178. https://doi org/10.1108/JOEPP-03-2017-0022

Wilkesmann, M., \& Wilkesmann, U. (2018). Industry 4.0 - organizing routines or innovations? VINE Journal of Information and Knowledge Management Systems, 48(2), 238-254. https://doi.org/10.1108/VJIKMS-04-2017-0019

Wilson, H.J., \& Daugherty, P.R. (2018). Collaborative intelligence: Humans and Al are joining forces. Harvard Business Review. Retrieved from https://hbr.org/2018/07/ collaborative-intelligence-humans-and-ai-are-joining-forces

Wood, G., \& Bischoff, C. (2020). Human resource management in Africa: Current research and future directions - Evidence from South Africa and across the continent. The International Journal of Human Resource Management, 32(17) 1-28. https://doi:10.1080/09585192.2019.1711443

Xu, M., David, J.M., \& Kim, S.H. (2018). The Fourth Industrial Revolution: Opportunities and challenges. International Journal of Financial Research, 9(2), 90-95. https:// doi.org/10.5430/ijfr.v9n2p90

Zhang, Y., \& Wildemuth, B. M. (2009). Qualitative analysis of content. In B.M Wildemuth (Ed.), Application of social research methods to questions in information and library science (pp. 308-319). Westport, CT: Libraries Unlimited. 